\title{
Analysis of Genetic Diversity in Sclerotium rolfsii Causing Collar Rot of Chilli by RAPD
}

\author{
A.T. Daunde ${ }^{1 *}$, K.T. Apet ${ }^{2}$ and R.L. Chavan ${ }^{3}$ \\ ${ }^{1}$ AICRP (Vegetable Crops), VNMKV, Parbhani (MS), India \\ ${ }^{2}$ Department of Plant Pathology, VNMKV, Parbhani (MS), India \\ ${ }^{3}$ Vilasrao Deshmukh College of Agricultural Biotechnology, VNMKV, Parbhani (MS), India \\ *Corresponding author
}

\section{A B S T R A C T}

\begin{tabular}{|l|}
\hline K e y w o r d s \\
Chilli, Sclerotium rolfsii, \\
Genetic diversity, \\
Primers, RAPD, Cluster
\end{tabular}

Keywords

Chilli, Sclerotium rolfsii, Primers, RAPD, Cluster

Accepted:

Available Online:

10 December 2018
Collar rot of chilli caused by Sclerotium rolfsii Sacc. is currently occurring in chilli growing areas of Marathwada region in India. The genetic diversity among eight chilli $S$. rolfsii isolates collected from eight districts covering various geographic areas of Marathwada region of Maharashtra state were analysed using random amplified polymorphic DNA (RAPD) using five random primers. Size of DNA fragments amplified by the five primers ranged from $0.1 \mathrm{~Kb}$ to $10 \mathrm{~Kb}$ indicating polymorphism among $S$. rolfsii isolates. RAPD banding profiles with five different random primers viz., OPA-2, OPA-3, OPA-13, OPA-19 and OPC-5 revealed the existence of genetic variability among the isolates of $S$. rolfsii and were classified into two main clusters. Cluster A contains one isolate $\left(\mathrm{SrA}_{1}\right)$ i.e. highly virulent. Whereas, Cluster $\mathrm{B}$ is sub-divided into cluster $\mathrm{B} 1\left(\mathrm{SrB}_{2}\right.$, $\mathrm{SrO}_{7}, \mathrm{SrH}_{3}, \mathrm{SrJ}_{4}, \mathrm{SrL}_{5}$ and $\left.\mathrm{SrP}_{8}\right)$ and $\mathrm{B} 2\left(\mathrm{SrN}_{6}\right)$. Hence, the present investigation confirmed the diversity among the different geographical isolates.

\section{Introduction}

Chilli (Capsicum annuum L.) is mainly cultivated for green fruits as table purpose and dry chilli as spice. Chilli crop suffers from a number of fungal, bacterial, nematode and many viral diseases. Recently, the collar rot caused by Sclerotium rolfsii Sacc. is becoming sever disease of chilli in India. Crop losses up to $16-80$ per cent due to collar rot disease have been reported by many researchers in this crop (Wangikar et al., 1988; Singh and Dhancholia, 1991; Mathur and Gurjar, 2001). S. rolfsii, is cosmopolitan soilborne necrotrophic plant pathogens, infects more than 500 different plant species worldwide and causes collar rot, root rot and stem rot diseases (Punja, 1985; $\mathrm{Xu}, 2009)$. The amount and distribution of genetic variability of plant pathogen populations affect the efficacy of control strategies of plant diseases. Therefore, the studies on the genetic structure of pathogen populations should be an important step when planning management programmes aimed to prevent or control the disease. Random amplified polymorphic DNA (RAPD) molecular techniques have been used to investigate genetic diversity of $S$. rolfsii (Prasad et al., 2010; Durgaprasad et al., 2008; Rasu et al., 2013) 
Genetic variability of $S$. rolfsii populations infesting chilli plant production areas of Marathwada state of Maharashtra, India have not been reported yet. It is important to understand the epidemiology and genetic diversity of $S$. rolfsii to control plant diseases by chemical and cultural methods. Additional insight into Sclerotium problems might be achieved via molecular characterization of local isolates. Hence, the study was undertaken to carry out investigation on the variation among Sclerotium isolates of Marathwada region of Maharashtra, India with regard to genetic variation to group them and variability was confirmed by using molecular studies.

\section{Materials and Methods}

\section{Fungal isolates}

A roving survey of farmers chilli fields was conducted in the agroclimatic zones of Marathwada region of Maharashtra during Kharif 2016-17, to collect chilli plants showing the typical symptoms of collar rot $(S$. rolfsii) and then washed with tap water and rinsed with sterile distilled water. Diseased collar regions were cut into small pieces and then surface sterilized in $0.1 \%$ mercuric chloride for 30 seconds and repeatedly washed with sterilized distilled water to remove traces of mercury and then transferred to Potato Dextrose Agar (PDA) Medium and incubated at $27 \pm 1^{\circ} \mathrm{C}$. Fungal mycelium developed on PDA medium was finally transferred to PDA slants and incubated at $27 \pm 1^{\circ} \mathrm{C}$ to obtain pure culture of $S$. rolfsii.

A total of eight isolates of $S$. rolfsii, one each representing eight districts and covering various geographic regions of Marathwada region of Maharashtra state collected were isolated, purified and identified. Eight isolates of $S$. rolfsii from chilli fields were collected from eight districts of Marathwada region viz.,
Aurangabad, Beed, Hingoli, Jalna, Latur, Nanded, Osmanabad and Parbhani. According to districts, the isolates were designated as $\mathrm{SrA}_{1}, \mathrm{SrB}_{2} \mathrm{SrH}_{3} \mathrm{SrJ}_{4} \mathrm{SrL}_{5} \mathrm{SrN}_{6} \mathrm{SrO}_{7}$ and $\mathrm{SrP}_{8}$ respectively.

\section{Isolation genomic DNA}

The total genetic DNA of $S$. rolfsii isolates was extracted from mycelium using Cetyl trimethyl ammonium bromide (CTAB) extraction method (Doyle and Doyle, 1990). Fungal mat of $0.5 \mathrm{~g}$ grounded to fine powder in liquid nitrogen and transferred to sterile eppendorf tube. To this, $1 \mathrm{ml}$ of extraction buffer was added and incubated for $1 \mathrm{hr}$ in water bath at $65^{\circ} \mathrm{C}$. A gentle inversion was done at every 10 minutes interval. Then the tubes were centrifuged at $10,000 \mathrm{rpm}$ for 10 min at room temperature. The supernatant was transferred into other tubes. To the supernatant equal $\mathrm{ml}$ of chloroform and isoamyl alcohol (24:1) and RNase $(1 / 100 \mu \mathrm{l})$ was added and incubated at room temperature for $10 \mathrm{~min}$.

The tubes were centrifuged at $10,000 \mathrm{rpm}$ for $10 \mathrm{~min}$, separated the supernatant and added 0.6 vol. of ice cold isopropanol $(300 \mu \mathrm{l})+0.1$ vol. of sodium acetate $(50 \mu \mathrm{l})$ and incubated at $-20{ }^{0} \mathrm{C}$ for overnight. Next day, the tubes were centrifuged at $13,000 \mathrm{rpm}$ for $20 \mathrm{~min}$ at $4{ }^{\circ} \mathrm{C}$, the supernatant was discarded and the pellet washed with 70 per cent ethanol and centrifuged at $13,000 \mathrm{rpm}$ for $20 \mathrm{~min}$ at $4{ }^{0} \mathrm{C}$. Again, the supernatant discarded, the pellet air dried and dissolved in $100 \mu \mathrm{l}$ of sterile distilled water or TE. The DNA samples were stored at $-20{ }^{\circ} \mathrm{C}$ for further studies.

\section{Qualitative and quantitative analysis of DNA}

The quality of extracted DNA was analysed by means of agarose gel electrophoresis $(0.8$ $\%$ ), followed by ethidium bromide staining $(0.5 \mathrm{mg} / \mathrm{ml})$. 
Spectrophotometer was used for quantitative analysis of the DNA of the test isolates. Five $\mu \mathrm{l}$ of DNA sample was added in cuvette carrying $0.995 \mu \mathrm{l}$ of sterile $\mathrm{H}_{2} \mathrm{O}$ and absorbance was measured at $280 \mathrm{~nm}$ wavelength. Similarly, the purity of DNA was checked by measuring the ratio of $\mathrm{OD}$ at A260/A280 nm. The quantification of DNA was calculated by using following formula.

$\operatorname{DNA}(\mu \mathrm{g} / \mu \mathrm{l})=\frac{\text { OD at } 260 \mathrm{~nm} \times \text { Dilution factor } \times 50}{1000}$

\section{RAPD analysis of $S$. rolfsii isolates}

The Polymerase Chain Reaction (PCR) protocol for RAPD reaction was optimized with various PCR components used for molecular characterization and thermal cycler programme as detailed below.

Master mix (24 $\mu \mathrm{l})$ containing all of the above reactants, except template DNA were dispensed in autoclaved PCR tubes $(0.2 \mathrm{ml})$. Genomic DNA of each isolate was added to the individual tubes containing the master mix. The content of each tube was mixed by tapping with fingers, followed by a brief spun to collect the content at bottom of the tube. These tubes were placed in Thermocycler (Eppendorf) and subjected to PCR according to the standardized protocol given below.

\section{Standardized PCR protocols for amplification of DNA}

A PCR master mix in sterile distilled water with all of the above mentioned compounds in required quantities were prepared and amplifications were done through thermal cycler, using following PCR conditions.

The amplified RAPD product was separated by electrophoresis in 1.5 per cent agarose gel with $1 \mathrm{X}$ TAE buffer, stained with ethidium bromide $(0.5 \mu \mathrm{g} / \mathrm{ml})$ at $90 \mathrm{~V}$ for 1 to $1.5 \mathrm{hrs}$. and photographed using gel documentation system (Alpha Innotech, USA). The sizes of the amplification product were estimated using $100 \mathrm{bp}$ to $1 \mathrm{~kb}$ ladder (Fermentas, UK). The polymorphism was detected by comparing RAPD product of the test isolates of $S$. rolfsii.

\section{Data scoring and analysis}

The amplified profiles for all the primers were compared with each other and the bands of DNA fragment were scored as ' 1 ' for the presence and ' 0 ' for the absence of a band generating the ' 0 ', ' 1 ' matrices.

The genetic similarity coefficient was estimated using NTSYS-PC 2.02i software programme (Rohlf, 2000). The clustering was done and dendrogram was drawn by following unweighted pair group with arithmetic mean (UPGMA) routine, using the above programme. Other parameters computed were

Polymorphism $(\%)=\frac{\text { No. of polymorphic bands }}{\text { Total No. of bands }} \times 100$

\section{Results and Discussion}

\section{DNA fingerprinting profile}

The RAPD-PCR protocol described by Chavan (2004) was used with some modifications to produce DNA fingerprinting profile of 8 fungal isolates of $S$. rolfsii (Table 1, and Fig. 1, 2, 3, 4 and 5).

The PCR amplification reaction was optimized by varying concentration of PCR components. Amplification reaction was carried out in $25 \mu \mathrm{l}$ reaction mixtures containing $30 \mathrm{ng}$ of fungal genomic DNA, 1X PCR buffer, $1.5 \mathrm{mM} \mathrm{MgCl} 2,0.25 \mathrm{mM}$ dNTPs, 0.41 pmol primers and $1.25 \mathrm{U}$ of Taq DNA polymerase. PCR amplification was performed in master cycler gradient, 
Eppendorf PCR thermocycler, and the program consisted of an initial denaturing at $94{ }^{0} \mathrm{C}$ for $5 \mathrm{~min}$, followed by 40 cycles comprising denaturation at $94{ }^{0} \mathrm{C}, 1 \mathrm{~min}$, annealing at $36{ }^{\circ} \mathrm{C}$ and extension of $2 \mathrm{~min}$. at $72{ }^{0} \mathrm{C}$. The final extension was set at $72{ }^{\circ} \mathrm{C}$ for 10 min. PCR amplified product was separated by electrophoresis on $1.2 \%$ agarose gel in $1 \mathrm{X}$ TAE buffer, stained with Ethidium bromide and visualized under gel documentation system.

The PCR amplification reaction was optimized by varying concentration of PCR components. Amplification reaction was carried out in $25 \mu \mathrm{l}$ reaction mixtures containing $30 \mathrm{ng}$ of fungal genomic DNA, 1X PCR buffer, $1.5 \mathrm{mM} \mathrm{MgCl} 2,0.25 \mathrm{mM}$ dNTPs, 0.4 pmol primers and $1.25 \mathrm{U}$ of Taq DNA polymerase. PCR amplification was performed in master cycler gradient, Eppendorf PCR thermocycler, and the program consisted of an initial denaturing at $94{ }^{0} \mathrm{C}$ for $5 \mathrm{~min}$, followed by 40 cycles comprising denaturation at $94{ }^{0} \mathrm{C}, 1 \mathrm{~min}$, annealing at $36{ }^{\circ} \mathrm{C}$ and extension of $2 \mathrm{~min}$. at $72{ }^{0} \mathrm{C}$. The final extension was set at $72{ }^{\circ} \mathrm{C}$ for $10 \mathrm{~min}$. PCR amplified product was separated by electrophoresis on $1.2 \%$ agarose gel in $1 \mathrm{X}$ TAE buffer, stained with Ethidium bromide and visualized under gel documentation system.

\section{Diversity analysis using RAPD marker}

The genomic DNA of 8 isolates of $S$. rolfsii isolated from collar rot diseased specimens of chilli was subjected for PCR amplification by using RAPD primers (Table 1). Initially 26 random primer viz., OPA, OPB and OPC series were screened (random primer kit $\mathrm{A}$ and C, Operon Tech., USA). Among these, 5 primers produced large number of reproducible amplicons, which were employed for molecular characterization of the 8 test isolates (Fig. 1, 2, 3, 4 and 5).
The 8 isolates of $S$. rolfsii obtained from three different agro-climatic zones viz., Scarcity zone Assured rainfall zone and Moderate rainfall zone of Marathwada region of the Maharashtra was characterized at molecular level by using 26 random primers from OPA, OPB and OPC series i.e. OPA $(03,05,06,08$, 09, 13, 16, 18 and 20), OPB $(02,05,07,11$, $12,13,16$ and 17) and OPC (01, 03, 04, 05, $10,13,15,18$ and 20). Results indicated that among the primers tested viz., OPA-2, OPA-3, OPA-13 OPA-19, and OPC-5 were found more polymorphic and generated significant data for discrimination of the test isolates. The average size of amplicons generated by the test primers was ranged between $0.1 \mathrm{~Kb}$ to 10 $\mathrm{Kb}$. The RAPD-PCR amplification result showed that about 5 RAPD primers generated a total of 21 bands, in which 17 bands were found polymorphic and 4 bands found as monomorphic. The primer OPA19 was found more informative, as generate total number of 7 bands, followed by the primers, OPA-2, OPA-3 OPA13 (each @ 4). Primer OPC-5 generated lowest number of bands (2 band) (Table 1 and Fig. 6). In OPA-19 primer 6 bands found polymorphic and one band was found as monomorphic, with 85.71 per cent polymorphism and in other primers all amplicons were found polymorphic with 75 per cent polymorphism.

\section{Cluster analysis of RAPD DNA fingerprint}

The data obtained by RAPD markers was analyzed by NTSYS pc $2.02 \mathrm{i}$ and dendrogram was depicted by using Jaccard's Similarity Coefficient and genetic similarity matrix was obtained. The similarity coefficient value ranged from 0.37 to 0.94 across 8 isolated genotype different zone of Marathwada region indicating high degree of genetic variation. The highest value for similarity was obtained for $\mathrm{SrJ}_{4}, \mathrm{SrH}_{3}$ isolates whereas, $\mathrm{SrO}_{7}, \mathrm{SrA}_{1}$, $\mathrm{SrN}_{6}$ and $\mathrm{SrH}_{3}$ isolates showed lowest similarity (Table 2 and Fig. 8). 
RAPD analysis of $S$. rolfsii isolates

\begin{tabular}{|r|l|l|l|}
$\begin{array}{l}\text { Sr. } \\
\text { No. }\end{array}$ & PCR Components & $\begin{array}{l}\text { Required } \\
\text { Concentration }\end{array}$ & $\begin{array}{l}\text { Volume/ } \\
\text { reaction }\end{array}$ \\
\hline 1 & PCR Buffer & $1 \mathrm{X}$ & $2.5 \mu 1$ \\
\hline 2 & $\mathrm{MgCl}_{2}$ & $1.5 \mathrm{mM}$ & $1.5 \mu \mathrm{l}$ \\
\hline 3 & dNTP mix & $200 \mu \mathrm{m}$ & $0.2 \mu 1$ \\
\hline 4 & $\begin{array}{l}\text { Random Primers } \\
\text { (Kit- A and C operon tech) }\end{array}$ & $0.4 \mathrm{pmol}$ & $1 \mathrm{ml}$ \\
\hline 5 & Taq DNA Polymerase & $1.5 \mathrm{U}$ & $0.3 \mu 1$ \\
\hline 6 & Template DNA & $30 \mathrm{ng}$ & $1 \mu 1$ \\
\hline 7 & Nuclease free water & - & $18 \mu 1$ \\
\hline & Total & - & $\mathbf{2 5 . 0} \boldsymbol{\mu l}$ \\
\hline
\end{tabular}

Standardized PCR protocols for amplification of DNA

\begin{tabular}{|r|l|c|c|c|}
\hline $\begin{array}{c}\text { Sr. } \\
\text { No. }\end{array}$ & \multicolumn{1}{|c|}{ Steps } & $\begin{array}{c}\text { Temperature } \\
\left({ }^{\mathbf{0}} \mathbf{C}\right)\end{array}$ & $\begin{array}{c}\text { No. of } \\
\text { cycles }\end{array}$ & $\begin{array}{c}\text { Duration } \\
(\mathbf{m i n})\end{array}$ \\
\hline $\mathbf{1}$ & Initial Denaturation & 94 & 1 & 4 \\
\hline $\mathbf{2}$ & Denaturation & 94 & & 1 \\
\hline $\mathbf{3}$ & Annealing & 37 & 40 & 1 \\
\hline $\mathbf{4}$ & Primer Extension & 72 & & 2 \\
\hline $\mathbf{5}$ & Final Extension & 72 & 1 & 10 \\
\hline $\mathbf{6}$ & Final hold & 4 & - & $\begin{array}{l}\text { Until gel } \\
\text { electrophoresis } \\
\text { was done }\end{array}$ \\
\hline
\end{tabular}

Table.1 List of RAPD primers and polymorphism generated during fingerprint analysis of 8 isolates of $S$. rolfsii

\begin{tabular}{|l|l|l|c|c|c|c|}
$\begin{array}{c}\text { Sr. } \\
\text { No. }\end{array}$ & Primer & \multicolumn{1}{|c|}{$\begin{array}{c}\text { Sequences } \\
\left(\mathbf{5}^{\prime}-\mathbf{3}^{\prime}\right)\end{array}$} & $\begin{array}{c}\text { Total } \\
\text { Loci }\end{array}$ & $\begin{array}{c}\text { polymorphic } \\
\text { Loci }\end{array}$ & $\begin{array}{c}\text { Monomorphic } \\
\text { Loci }\end{array}$ & $\begin{array}{c}\text { Polymorphism } \\
(\mathbf{\%})\end{array}$ \\
\hline $\mathbf{1}$ & OPA-2 & TGCCGAGCTG & 4 & 3 & 1 & 75.00 \\
\hline $\mathbf{2}$ & OPA-3 & AGTCAGCCAC & 4 & 3 & 1 & 75.00 \\
\hline $\mathbf{3}$ & OPA13 & CAGCACCCAC & 4 & 3 & 1 & 75.00 \\
\hline $\mathbf{4}$ & OPA19 & CAAACGTCGG & 7 & 6 & 1 & 85.71 \\
\hline $\mathbf{5}$ & OPC-5 & GATGACCGCC & 2 & 2 & 0 & 100.00 \\
\hline & Total & & $\mathbf{2 1}$ & $\mathbf{1 7}$ & $\mathbf{4}$ & $\mathbf{8 2 . 1 4}$ \\
\hline
\end{tabular}


Table.2 The similarity matrix representing coefficient of similarity among eight isolates of $S$. rolfsii based on RAPD marker

\begin{tabular}{|l|l|l|l|l|l|l|l|l|}
\hline Isolates & $\mathbf{S r A}_{\mathbf{1}}$ & $\mathbf{S r B}_{\mathbf{2}}$ & $\mathbf{S r H}_{\mathbf{3}}$ & $\mathbf{S r J}$ & $\mathbf{S r L}_{\mathbf{5}}$ & $\mathbf{S r N}_{\mathbf{6}}$ & $\mathbf{S r O}_{\mathbf{7}}$ & $\mathbf{S r P}_{\mathbf{8}}$ \\
\hline $\mathbf{S r A}_{\mathbf{1}}$ & 1 & & & & & & & \\
\hline $\mathbf{S r B}_{\mathbf{2}}$ & $\mathbf{0 . 3 7 5}$ & 1 & & & & & & \\
\hline $\mathbf{S r H}_{\mathbf{3}}$ & 0.470 & 0.631 & 1 & & & & & \\
\hline $\mathbf{S r J}_{\mathbf{4}}$ & 0.444 & 0.684 & $\mathbf{0 . 9 4 4}$ & 1 & & & & \\
\hline $\mathbf{S r L}_{\mathbf{5}}$ & 0.466 & 0.750 & 0.823 & 0.777 & 1 & & & \\
\hline $\mathbf{S r N}_{\mathbf{6}}$ & 0.466 & 0.400 & 0.631 & 0.600 & 0.550 & 1 & & \\
\hline $\mathbf{S r O}_{\mathbf{7}}$ & 0.400 & 0.687 & 0.666 & 0.631 & 0.800 & 0.421 & 1 & \\
\hline $\mathbf{S r P}_{\mathbf{8}}$ & 0.411 & 0.500 & 0.736 & 0.789 & 0.578 & 0.578 & 0.611 & 1
\end{tabular}

Fig.1 RAPD fingerprint profile of 8 isolates of $S$. rolfsii by using primer OPA-2, Lane MMarker (1 kb DNA ladder); Lanes 1-8 isolates

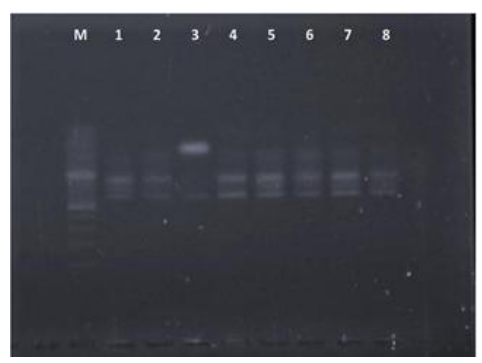

Fig.2 RAPD fingerprint profile of 8 isolates of $S$. rolfsii by using primer OPA-3, Lane MMarker (1 kb DNA ladder); Lanes 1-8 isolates

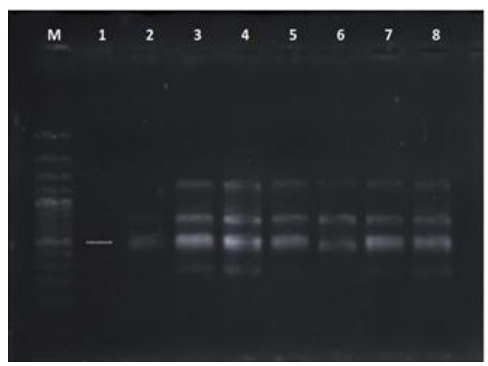

Fig.3 RAPD fingerprint profile of 8 isolates of $S$. rolfsii by using primer OPA-13, Lane MMarker (1 kb DNA ladder); Lanes 1-8 isolates

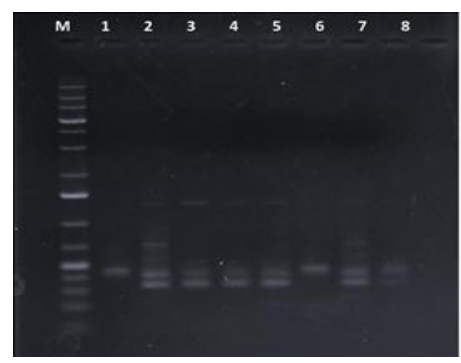


Fig.4 RAPD fingerprint profile of 8 isolates of $S$. rolfsii byusing primer OPA-19, Lane MMarker (1 kb DNAladder); Lanes 1-8 isolates

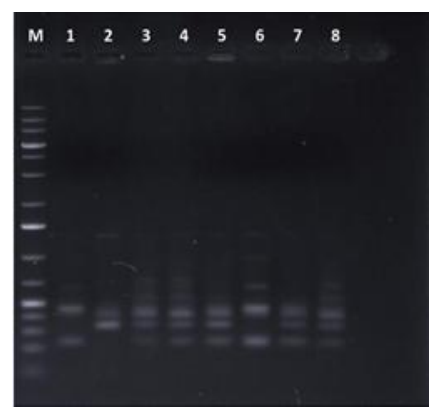

Fig.5 RAPD fingerprint profile of 8 isolates of $S$. rolfsii by using primer OPC-5, Lane MMarker (1 kb DNA ladder); Lanes 1-8 isolates

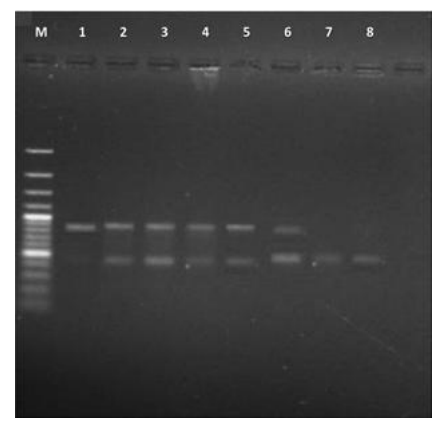

Fig.6 Dendrogram based on RAPD analysis depicting relationship between eight isolates of chilli $S$. rolfsii

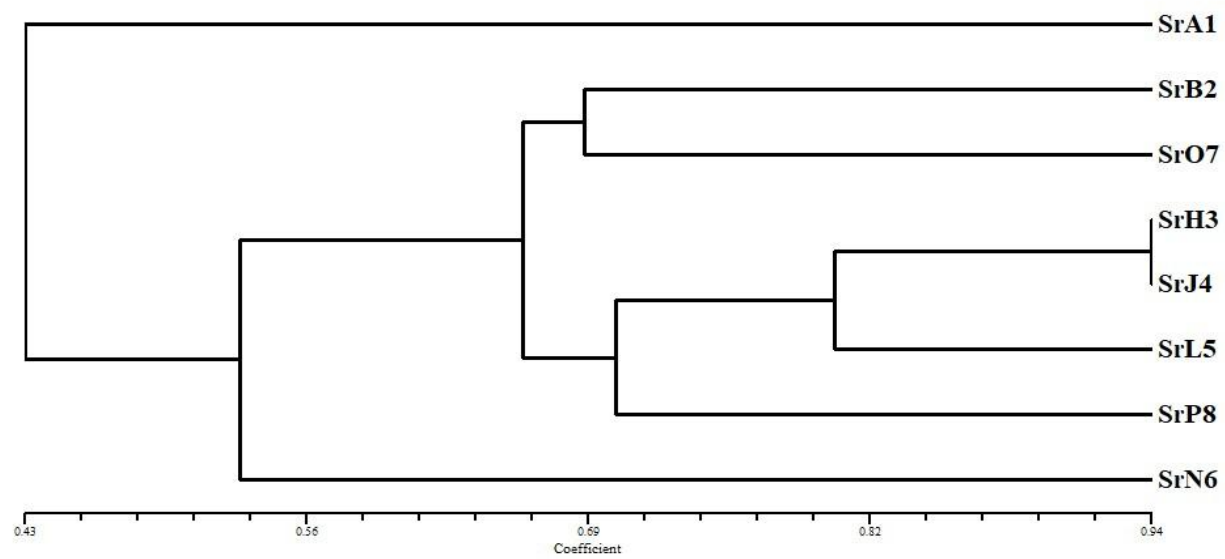

Based on the proximity matrix obtained from Jaccard's coefficient Sequential Agglomerative Hierarchical Non-Overlapping (SAHN) clustering was done using Unweighted Pair Group Method with Arithmetic Averages (UPGMA) method.
Dendrogram generated based on UPGMA analysis of RAPD analysis show that 8 isolated can be grouped into 2 major cluster viz., A and B. Major Cluster A contain only one isolate $\mathrm{SrA}_{1}$. The major cluster $\mathrm{B}$ divided into two sub-cluster, mainly B1 and B2. Sub 
cluster B1 shows six isolates $\mathrm{SrB}_{2}, \mathrm{SrO}_{7}$, $\mathrm{SrH}_{3}, \mathrm{SrJ}_{4}, \mathrm{SrL}_{5}$ and $\mathrm{SrP}_{8}$. Sub cluster B2 shows only one isolates $\mathrm{SrN}_{6}$. Out of this, isolates $\mathrm{SrH}_{3}$ and $\mathrm{SrJ}_{4}$ shows 94 per cent similarity and also shares same ancestry. The isolates $\mathrm{SrA}_{1}, \mathrm{SrO}_{7}$ and $\mathrm{SrB}_{2}, \mathrm{SrN}_{6}$ were found to be distantly related showing 40 per cent similarity.

The cluster $\mathrm{B}$ was distinct from cluster $\mathrm{A}$ containing one isolate; $\mathrm{SrA}_{1}$ showing 43 per cent similarity. The range of dendrogram was observed to be in between 40 to 94 per cent.

These results are in agreement with the findings of Francisco and Patrica, (2001) reported genetic variability of the $S$. cepivorum Berk. Cause of white rot of garlic by RAPD and showed that dendrogram analysis of data had a tendency of isolates to group according to the geographic precedence. Durgaprasad et al., (2008) prepared RAPD profiles of isolates of $S$. rolfsii causing stem rot of peanut with random primers, viz., OPA-01, OPA-12, OPA-17, OPA-18 and OPA-20 which reflected the genetic diversity among the isolates with the formation of two clusters. Rasu et al., 2013 isolated $S$. rolfsii from different geographic locations and examined their genomic variations and prepared RAPD banding patterns for 10 isolates of $S$. rolfsii using five random primers which clearly indicated that genetic variability existed among $S$. rolfsii isolates. Kumar et al., (2010) studied genetic diversity among 15 isolates of $S$. oryzae collected from major rice growing areas of Haryana in India based on DNA polymorphism using 22 RAPD primers. Their findings proved the genetic variability among the tested $S$. oryzae, since they divided into different sub-clusters. Parvin et al., (2016) used RAPD polymorphism as a tool to determine genetic variation among isolates of $S$. rolfsii. They mentioned that DNA fingerprinting by RAPD prompted the grouping of eight $S$. rolfsii isolates. Rasu et al., (2013) established RAPD banding patterns for ten $S$. rolfsii isolates using five random primers. Their findings revealed that all the isolates have about $54 \%$ similarity coefficient indicating that they were genetically varied by their unique banding patterns. This indicated genetic variability existing among $S$. rolfsii isolates. Similar results of molecular/genetic variability among isolates of Sclerotium spp. were reported by several workers (Punja and Sun, 2001; Tyson et al., 2002; Prasad et al., 2010; Gawande et al., 2013).

Thus, in present studies molecular variability was observed among the isolates of S. rolfsii may be attributed to their geographic distribution in the Marathwada region of Maharashtra state, long term influence of weather parameters at a particular location and ability of the pathogen to adopt the chilli varieties grown.

\section{References}

Chavan, R. L. 2004. Study of genetic variability among isolates of Alternaria species infecting sunflower: cultural, morphological, pathological, biochemical and molecular investigations. M. Sc. (Agri.) Thesis, M.A.U. Parbhani, PP: $1-72$.

Doyle, J. J. and Doyle, J. L. 1990. A rapid total DNA preparation procedure for fresh plant tissue. Focus. 12: 13-15.

Durgaprasad, S., Eswara Reddy, N. P., Chittem, K., Bhaskara Reddy, B., Sudhakar, P. and Rao, S. V. R. K. 2008. Variability among the isolates of Sclerotium rolfsii Sacc. causing stem rot of peanut (Arachis hypogea L.). Conference: The Rovira Rhizosphere Symposium, Adelaide, Australia, pp. 72-80. 
Francisco, L. M. and Patrica, P. N. 2001. Characterization molecular de airlodos de $S$. cepivorum mediance analysis gel polimorfirmo de los fragmentosamplificados al azar. Acta universitaria, Agosto and universsidad de Guanajuato, Guanajvato, Mexico. 11(2): 44-60.

Gawande, S. P., Borkar, S. G., Chimote, V. P. and Sharma, A. K. 2013. Determination of genetic diversity in Sclerotium rolfsii and Sclerotium delphinii by using RAPD and ISSR markers. Vegetos. 26 (SP): 39-44.

Kumar A., Singh, R., Boora, K. S. and Jalali, B. L. 2010 Genetic diversity in Sclerotium oryzae population of rice based on random amplified polymorphic DNA markers. Indian Phytopathol. 63: 418-420.

Mathur, K. and Gurjar, R. B. S. 2001. Sclerotium rolfsii- a new threat to chilli in Rajasthan. J. Mycol. Pl. Pathol. 31: 261.

Parvin, N., Bilkiss, M., Nahar, J., Siddiqua, M. K. and Meah, M. B. 2016. RAPD analysis of Sclerotium rolfsii isolates causing collar rot of eggplant and tomato. Int. J. Agril. Res. Innov. Tech. 6 (1): 47-57

Prasad, D., Basha, S. T., Peddanarappa, N. and Reddy, G. E. 2010. Molecular variability among the isolates of Sclerotium rolfsii causing stem rot of groundnut by RAPD, ITS-PCR and RFLP. Eur Asian J. BioSci. 4: 80-87.

Punja, Z. K. 1985. The biology, ecology and control of Sclerotium rolfsii. Ann. Rev. Phytopathol. 23: 97-127.
Punja, Z. K. and Sun, L. J. 2001. Genetic diversity among mycelial compatibility groups of Sclerotium rolfsii (telemorph Athelia rolfsii) and S. delphinii. Mycol. Res. 105 (5): 537-546.

Rasu, T., Sevugapperumal, N., Thiruvengadam, R. and Ramasamy, S. 2013. Morphological and genomic variability among Sclerotium Rolfsii populations. BioScan. 8 (4): 14251430.

Rohlf, F. J. 2000. NTSYS-PC: Numerical Taxonomy and Multivariate Analysis System, Version 2.02i, Setauket (NY): Exeter Biological Software, New York.

Singh, D. and Dhancholia, S. 1991. A noteworthy disease of brinjal caused by Sclerotium rolfsii Sacc. Himachal Pradesh J. Agric. Res. 17 (1\&2): 119120.

Tyson, J. L., Ridgway, H. J., Fullerton, R. A. and Stewart, A. 2002. Genetic diversity in New Zealand populations of Sclerotium cepivorum, New Zealand. J. Crop \& Hort. Sci.30: $37-$ 48.

Wangikar, P. D., Somani, R. B. and Bobade, K. P. 1988. Sclerotium collar rot a new menace to chilli in Vidarbha. PKV Res. J. 12 (1): 88-89.

$\mathrm{Xu}$, Y. H. 2009. Occurrence and integrated management of chilli root rot caused by Sclerotium rolfsii. Plant Doctor. 22: $19-20$.

\section{How to cite this article:}

Daunde, A.T., K.T. Apet and Chavan, R.L. 2018. Analysis of Genetic Diversity in Sclerotium rolfsii Causing Collar Rot of Chilli by RAPD. Int.J.Curr.Microbiol.App.Sci. 7(12): 91-99. doi: https://doi.org/10.20546/ijcmas.2018.712.012 